\title{
Asien og Globaliseringens Ocean
}

\section{Anders Hansen}

\section{En fredelig udvikling i det Arabiske Hav og den Bengalske Bugt kræver øget forståelse mellem Kina og Indien}

Kishore Mahbubani: The New Asian Hemisphere - The Irresistible Shift of Global Power to the East. New York, 2008 (Paperback Edition). Robert D. Kaplan: Monsoon. The Indian Ocean and the Future of American Power. Random House, New York, 2010.

Hvor verden vender sig, er et af de udenrigspolitiske eksperters yndede emner. At den vestlige verdens dominans og det amerikanske hegemoni er ved vejs ende, synes der at herske nogenlunde enighed om. Men når det gælder at få stillet fremtidsbrillerne ind, og give præcise bud på den type verdensorden vi får i stedet for, så kniber det noget med skarpheden.

De gængse forudsigelser går på, at vækstlandene Kina, Indien og Brasilien kommer til at få stadig større betydning, og at Asien, det største kontinent, bliver helt dominerende.
Denne pointe går blandt andet gennem den singaporeanske professor og fhv. diplomat, Kishore Mahbubanis bestseller.

Som det fremgår af bogens forord, så er han helt på det rene med, at det er et synspunkt, som folk i Vesten ikke nødvendigvis vil tage imod med kyshånd. Hvad Mahbubani forestiller sig er tre mulige scenarier for, hvordan verden vil udforme og udvikle sig.

Det første, og det han selv hylder, er 'modernitetens fremmarch' i Asien. Her skal modernitet forstås i en meget konkret forstand, hvor det handler om adgang til moderne faciliteter som elektricitet og forbedrede sanitære forhold. Men bag disse forbedringer ligger tillige en stadig stærkere tro på fremtiden, og på, at man som individ selv kan bidrage til at forbedre sine levevilkår. Det er den udvikling, fastslår Mahbubani, man i dag ser udspille sig i 
blandt andet Kina, og som Vesten gør klogt i at underst $\varnothing t t e$.

Den anden udviklingsmulighed er 'forskansning', som kan blive en realitet, hvis man fra vestlig side vælger at modarbejde den asiatiske fremmarch med politisk og økonomisk protektionisme.

Endelig er der den retning for fremtiden, som Mahbubani kalder 'Vestens Triumf'. Det er det scenario, han finder mindst sandsynligt, eftersom det har sit afset i politologen Francis Fukuyamas tanker fra 1989 om, at der ikke er noget alternativ til den vestlige politiske udviklingsmodel. For som Mahbubani med en vis grad af nydelse selv fremhæver, så viste den såkaldte forudsigelse om 'Historiens Afslutning' sig efterfølgende ikke at holde stik.

$\mathrm{Og}$ for at sætte den vestlige dominans' afslutning i relief henvises der i bogen til den britiske historiker, Angus Madison, som har regnet sig frem til, at de kinesiske og indiske økonomier var de største i verden i perioden fra det 1 . århundrede og frem til 1820. Med andre ord er det, vi ser ske i det 21. århundrede, slet og ret en tilbagevenden til verden som den var engang.

\section{Asiatisk rivalisering}

Asiatisk fremdrift er også et af omdrejningspunkterne i Robert D. Kaplans bog. Han går dog noget anderledes til værks end Mahbubani og har i stedet et mere geopolitisk sig- te, hvor rivaliseringen mellem de to store asiatiske giganter og den betydning det vil få for USA's position i området, er i fokus.

Den vestlige dominans, som har varet $i$ omegnen af et halvt årtusinde, er nu på retur og på vej til at blive erstattet af en række lande. Ikke sådan at forstå at der vil være et enkelt dominerende land eller en særlig alliance, men snarere en tilstedeværelse af flere spillere. Her vil USA stadig have en central rolle, og den amerikanske flåde vil forblive den største i området, men den relative forskel mellem USA, Kina og Indien på det sømilitære område vil blive mindre. Det vil blandt andet betyde, at det Indiske Ocean til få en tiltagende geopolitisk betydning. $\mathrm{Og}$ her er det Kaplans analyse, at vi er på vej hen imod en ny multipolær verdensorden med det Indiske Ocean som det kommende center.

Bogens hovedsigte synes således at være at give læseren et nyt (mentalt) kort over verden med fokus på 'the Greater Indian Ocean' området. Dette område, pointeres det, vil blive den prisme som det nye århundrede skal ses eller opfattes gennem på samme måde som Europakortet var ikonisk for forståelsen af det 20 . århundrede. Med Malaccastrædet som det 21. århundredes Fulda Gap. (Et lavtliggende område på grænsen mellem Østtyskland og Vesttyskland, som blev anset for særlig strategisk vigtigt under den kolde krig - ikke mindst i forsvaret af Vesttysklands fi- 


\section{LITTERATUR}

nansielle centrum, Frankfurt).

Det er jo noget af en arv at få med sig, men det gælder for det Indiske Ocean, at det er her globaliseringen udspiller sig. Den mellemøstlige olie, en livsnerve i den globale økonomi, befragtes herigennem, og det samme sker for en stor del af verdenshandlen.

At oceanet er ramme om handel er for så vidt ikke nyt. Det har det altid været. I perioder var det muslimske købmænd, som var de dominerende, og som udbredte islam til store dele af området. Men også andre har sat deres præg, herunder både indere og kinesere. Det samme gælder europæerne, som siden Vasco da Gama fandt søvejen rundt om Afrika, har været markant tilstede. Først repræsenteret af portugisere, men siden hen af blandt andre englændere, hollændere og franskmænd. Og efter Anden Verdenskrig med USA i front.

Det nye vi er vidne til i Kaplans optik, er, hvorledes "China seeks to expand its influence vertically, that is, reaching southward down to the warm waters of the Indian Ocean, India seeks to expand its influence horizontally, reaching eastward and westward to the borders of Victorian age British India, parallel to the Indian Ocean" (p. 10).

For Kina handler det om varetagelse af sikkerhedspolitiske interesser, herunder sikring af forsyningslinjer, og om at gøre sig fri af den geografiske spændetrøje, som man finder at Malaccastrædet er. For i modsætning til de to andre oceaner, Atlanterhavet og Stillehavet, er det indiske delvis lukket i hver ende af henholdsvis Rødehavet med Suezkanalen og Malaccastrædet.

I stedet er den strategiske ambition at blive i stand til at benytte havne i det Indiske Ocean. Det er grunden til, at Kina er involveret $\mathrm{i}$ udviklingen af havnefaciliteter i Gwadar - i den pakistanske del af Baluchistan, som ligger ud til det Arabiske Hav. Og tilsvarende årsagen til det kinesiske engagement $\mathrm{i}$ Burma, der har kystlinje med oceanets anden halvdel, den Bengalske Bugt.

Den udvikling følges meget tæt fra New Delhi, hvor man ser med bekymring på, hvordan Kina rykker nærmere. Et af de indiske modtræk er gennem den såkaldte Look East Policy, som blev sat i værk i 1991, og som går ud på at udvikle tættere relationer med primært ASEAN-landene, men siden hen også Japan, og altså lande der ligeledes ser med bekymring på den hastig voksende kinesiske indflydelse.

\section{Fremtiden for amerikansk magt}

For Kaplan er det her hvor 'the future of American power' kommer ind. USA skal være den balancerende magt. En position, som Kaplan pointerer, en række asiatiske lande, blandt andre Japan, Malaysia og Indonesien, støtter op om. 
Når en udvikling i den retning er mulig, er det fordi området er kendetegnet ved en høj grad af kompleksitet, som det ikke er muligt for et enkelt land eller alliance at dominere. Derfor kommer fremtiden snarere til at byde på nuancerede relationer aktørerne imellem frem for skabelse af store alliancer.

Det er positivt, finder Kaplan, eftersom det vil kunne medvirke til, at de magter som kommer til at dominere havene, vil have interesser $i$ at samarbejde. Og der er oplagte muligheder inden for piratbekæmpelse, terrorbekæmpelse eller afhjælpning under naturkatastrofer (tsunamien var en eksempel på, at den amerikanske flåde spillede en stor rolle i hjælpearbejdet). Men den helt centrale samarbejdsmulighed ligger selvsagt inden for handel - et område alle landene har en fælles interesse $\mathrm{i}$.

Kaplans eget bud på en mulig fredelig udvikling for det Indiske Ocean-område, og omfattende både Indien, Kina og USA, lyder således: "Therefore, a peaceful transition away from American unipolarity at sea toward an American-Indian-Chinese condominium of sorts would be the first of its kind. Rather than an abdication of responsibility, such a transition would leave the Greater Indian Ocean in the free and accountable hands of indigenous Asi- an nations for the first time in five hundred years." (p. 293).

Om det bliver den fredelige udvikling, vi kommer til at se udspille sig i det Arabiske Hav og den Bengalske Bugt, har man selvsagt lov at håbe på, men det vil nok kræve netop en større grad af forståelse mellem Kina og Indien, end den man ser i dag. Til gengæld er det svært ikke at lade sig rive med af bogen, herunder den indlysende pointe om, at der i den måde verdenskort viser verden på, er en tendens til at det Indiske Ocean forsvinder lidt.

Bogen er særdeles velskrevet og bevæger læseren med monsoonens vinde rundt i både tid og rum. Vi besøger Oman, Bangladesh, Indonesien og slutter af med Zanzibar, for nu at vælge nogle ud. Til tider står man dog lidt uforstående over for de ganske mange ekskurser forfatteren gør undervejs, og som ikke alle synes at have en præcis betydning for den historie og de pointer, Kaplan ønsker at bringe til torvs.

Men at søstridskræfterne får større betydning i det 21. århundrede kommer klart og tydeligt frem.

Anders Hansen er historiker fra Københavns Universitet. Han har isar beskeftiget sig med moderne indisk historie, forholdet mellem Pakistan og Indien og folkemordsforskning. 